Egyptian Journal of Aquatic Biology \& Fisheries

Zoology Department, Faculty of Science,

Ain Shams University, Cairo, Egypt.

ISSN $1110-6131$

Vol. 22(5): 461 - 471 (2018)

www.ejabf.journals.ekb.eg

\title{
Length-weight relationship, condition factor and reproductive biology of the Thin-lipped grey mullet, Liza ramada (Risso, 1826) in Bardawil Lagoon, North Sinai, Egypt.
}

\author{
Attia A. O. El- Aiatt and Kariman A. Sh. Shalloof \\ Fisheries Biology Laboratory, National Institute of Oceanography and Fisheries, Egypt \\ Correspondence Author: dr_kariman88@yahoo.com
}

\section{ARTICLE INFO}

Article History:

Received: Nov. 28, 2018

Accepted: Dec.30, 2018

Online: Jan.2019

Keywords:

Bardawil Lagoon

North Sinai

Liza ramada

Reproductive biology

condition factor

Fecundity.

\begin{abstract}
This paper concentrates on the reproductive biology of the Thin-lipped grey mullet, Liza ramada. 1567 individuals were obtained monthly from the different landing sites of the Bardawil lagoon, North Sinai, Egypt during the fishing season from May to December, 2017. The length-weight relation was found as $0.0063 \mathrm{~L}^{3.0727}, 0.0087 \mathrm{~L}^{2.98}$ and $0.0095 \mathrm{~L}^{2.9505}$ for males, females and combined sexes respectivly. Monthly condition factor values were generally low in September, and the highest values were recorded in OctoberDecember. The reproduction period (expressed by Gonado Somatic Index GSI) was determined to be in November and December.Overall ratio of males to females (M: F) was 1: 1.28. The recorded lengths at first maturity $\left(\mathrm{L}_{\mathrm{m}}\right)$ was determined as $L_{m}=27.6$ and $28.9 \mathrm{~cm}$ for males and females respectively . The absolute fecundity increased with total length and described by the power equation $\mathrm{F}=27.958 \mathrm{~L}^{3.0135}\left(\mathrm{R}^{2}=0.9458\right)$. The relative fecundity gradually increased from 11661.8 to 36098.3 eggs per $\mathrm{cm}$. To protect Liza ramada in Bardawil Lagoon from exploitation, it is recommonded to ban the use of gears of illegal mesh sizes and other destructive fishing methods to permit the females to breed, grow, and recruit into the fisheries ground. Length at first maturity $\left(\mathrm{L}_{\mathrm{m}}\right)$ must be increased by widening the net mesh size to catch $L$. ramada of lengths greater than $29.0 \mathrm{~cm}$.
\end{abstract}

\section{INTRODUCTION}

Bardawil lagoon is one of the largest salt water lagoons in the northern coast of Sinai province of Egypt. Seven species (grey mullet, thin lip grey mullet, sea bream, sea bass, common sole, Egyptian sole, and shrimp) are centered of the lagoon (Mehanna et al., 2011) .Liza ramada plays an economical-fisheries vital roles in Egypt, since it constitute more than $12.3 \%$ of the total catch of Bardawil lagoon and about $35 \%$ of Mugilidae catch (GAFRD, 2016). The thin lipped (L. ramada) are euryhaline and diadromous species that enter coastal lagoons during early life stages to fulfilled growth previous to sexual maturation (Papa et al., 2003). Family (Mugilidae) has a worldwide distribution in warm waters, where its members grow well on algae and detritus (Keith et al., 2000). Descriptions of reproductive strategies or the evaluation of fecundity are essential topics in the discipline of the biology and population dynamics of fish species. This will extend our Knowledge about a state of 
a stock and improves standard assessments of many commercially precious fish species (Hunter et al., 1992 \& Murua et al., 2003).

This paper presents reproduction biology of the thin-lipped mullet, Liza ramada, in Bardawil lagoon as a basic step to launch a modern fishery management strategy for this species.

\section{MATERIALS AND METHODS}

The study was carried out in the Bardawil lagoon. The lagoon is separated from the Mediterranean Sea by a sandy bar with two narrow inlets. It is considered as a natural depression with range in depth from 0.3 to $5 \mathrm{~m}$. The surface water temperature varied between a minimum of $14.8^{\circ} \mathrm{C}$ during January to a maximum of $29.4^{\circ} \mathrm{C}$ in August, with annual mean of $22.7^{\circ} \mathrm{C}$ (Mehanna, 2014) .The salinity ranged from 48.46 in March to 51.86 ppt in September (Khalil et al., 2016) .The fishing is seasonal, begins from April to the end of December, (El -Ganainy et al., 2002). Monthly random samples (1567 individuals) of Thin-lipped grey mullet, Liza ramada were collected from the different landing sites of the Bardawil lagoon, North Sinai. The sampling period were lasted during the fishing season from May to December, 2017. In the laboratory, total lengths to the nearest centimeter and total weight to the nearest 0.1 gram were recorded. The relationship between length and weight was calculated using the formula $\mathrm{W}=\mathrm{a} \mathrm{L}^{\mathrm{b}}$ where $\mathrm{W}$ is the total weight in grams, $\mathrm{L}$ is the total length in centimeters and $\mathrm{a} \& \mathrm{~b}$ are constants whose values were estimated by the least square method.

The condition factor was computed monthly by the formula $\mathrm{Kc}=(\mathrm{W} * 100)$ / $\mathrm{L}^{3}$ (Hile, 1936), Where: $\mathrm{Kc}=$ condition factor, $\mathrm{W}=$ weight in gram, and $\mathrm{L}=$ length in centimeter. The sex, stage of maturity and fecundity of individual fish of 463 samples (Fig. 1) were recorded.

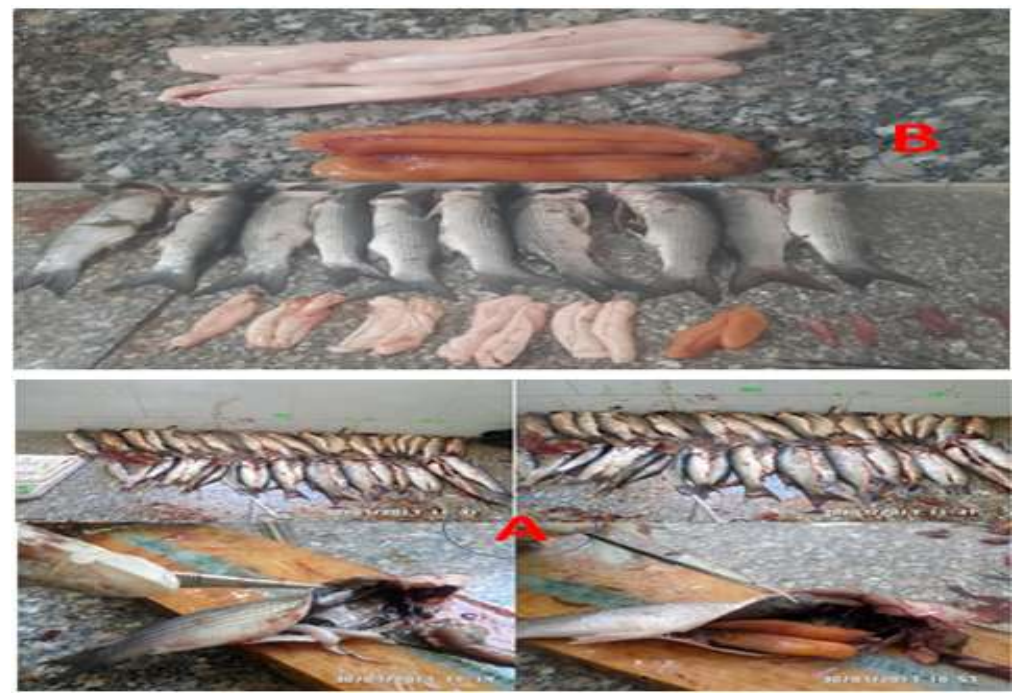

Fig. 1: Thin-lipped grey mullet, Liza ramada(A and B) in Bardawil lagoon.

The gonads after being removed were weighed to the nearest $0.01 \mathrm{~g}$. The ovaries were removed and preserved in $10 \%$ formalin for further studies. Maturity stages were determined with naked eye and by microscope in young specimens. In order to determine the spawning season, Gonado-Somatic index GSI was estimated as: (Weight of gonad / Weight of fish) $\times 100$ (Parameswarn et al., 1974). Sex ratio was calculated monthly. The length and age at first maturity $\left(\mathrm{L}_{50}\right)$, where $50 \%$ of fish 
reach their sexual maturity was estimated by fitting the maturation curve between the percentage maturities of fish corresponding to each length class interval.

The absolute fecundity $\left(\mathrm{F}_{\text {abs. }}\right)$ is defined as the number of mature eggs in the ovaries during the spawning season. 44 mature ovaries of adult females were used for length range from 21.2 to $36.7 \mathrm{~cm}$ total length. The gonads were removed, weighed to the nearest $0.001 \mathrm{gm}$ and placed in glass bottle with $10 \%$ formalin. Later, gonads washed and dried. Subsamples were taken from different parts of the ovaries. The ovarian tissue was removed and weighed to obtain the net eggs weight. The subsamples weighted (1gm), and eggs were well mixed, and placed on slide which was divided into squares. The eggs of twenty squares under the microscope were counted, and the total number of eggs in the subsample was counted. Then, the total fecundity was calculated as:

$\mathrm{F}=[($ Gonad Weight * Egg Number in the Subsample $(1 \mathrm{gm})$.$] (Yeldan and Avsar,$ 2000). The relative fecundity $\left(\mathrm{F}_{\text {rel }}\right)$ was calculated as: $\mathrm{F}_{\mathrm{rel}}=\mathrm{F}_{\mathrm{abs}} /$ (Body Length or Body weight). The relationship between the total length $\left(L_{t}\right)$ and fecundity using the least squares method was recorded.

\section{RESULTS}

A total of 1567 samples thin-lipped grey mullet, Liza ramada from the Bardwil lagoon were collected from May to December, 2017, ranged from 13 to $36.7 \mathrm{~cm}$, and the observed total weight from 22.3 to $441 \mathrm{~g}$. The length - weight relationship was described by the power equation as: $\mathrm{W}=0.0063 \mathrm{~L}^{\mathbf{3 . 0 7 2 7}}\left(\mathrm{R}^{2}=0.9602\right), \mathrm{W}=0.0087 \mathrm{~L}$ $2.98\left(\mathrm{R}^{2}=0.9537\right)$ and $\mathrm{W}=0.0095 \mathrm{~L}^{\mathbf{2 . 9 5 0 5}}\left(\mathrm{R}^{2}=0.9455\right)$ for males, females and combined sexes respectively (Figs.2, 3 and 4).

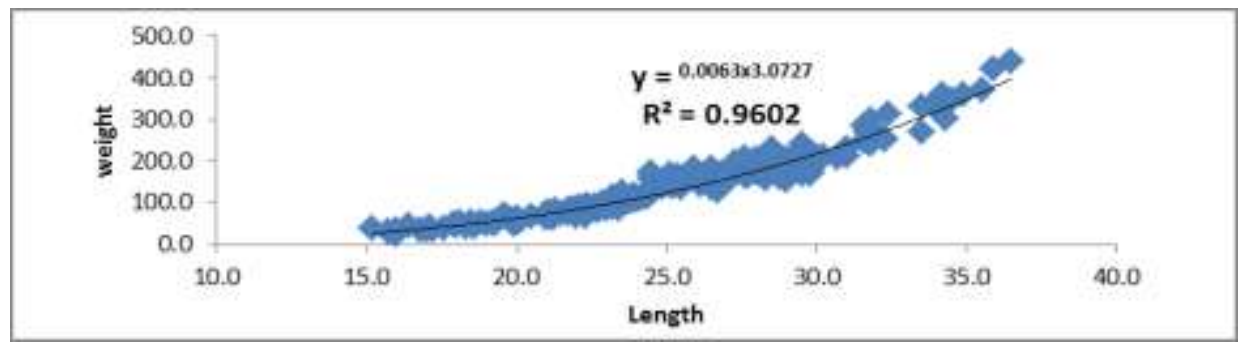

Fig. 2: Length weight relationship of males of Liza ramada in Bardawil lagoon 2017.

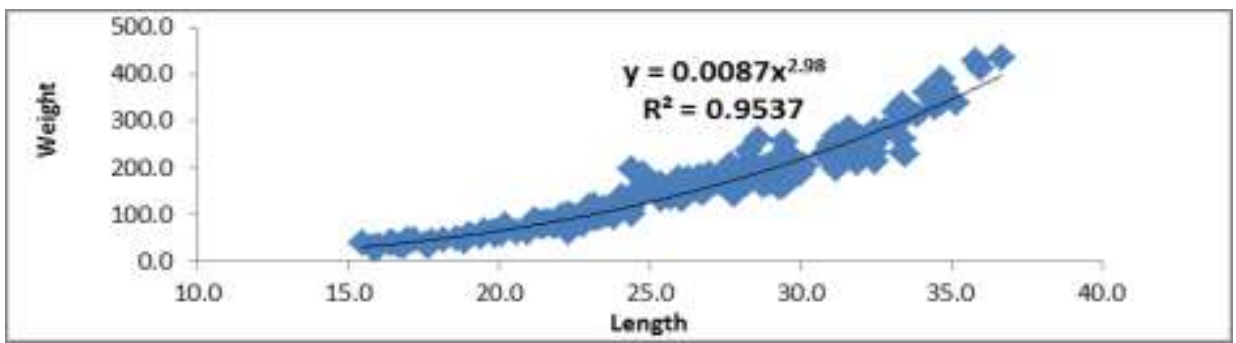

Fig. 3: Length weight relationship of females of Liza ramada in Bardawil lagoon 2017.

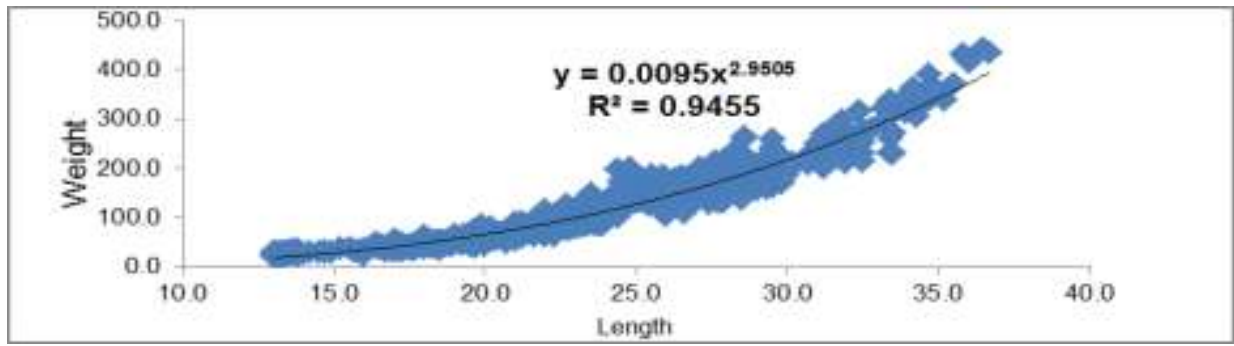

Fig. 4: Length weight relationship of combined sexes of Liza ramada in Bardawil lagoon 2017. 
Monthly mean condition factor for female, male and combined sexes were nearly similar for both sexes and were generally low in September, and the highest values were recorded in October-December (Fig. 5). A decline in (K) was observed during November in female accompanied by a slight increase in males in the same month.

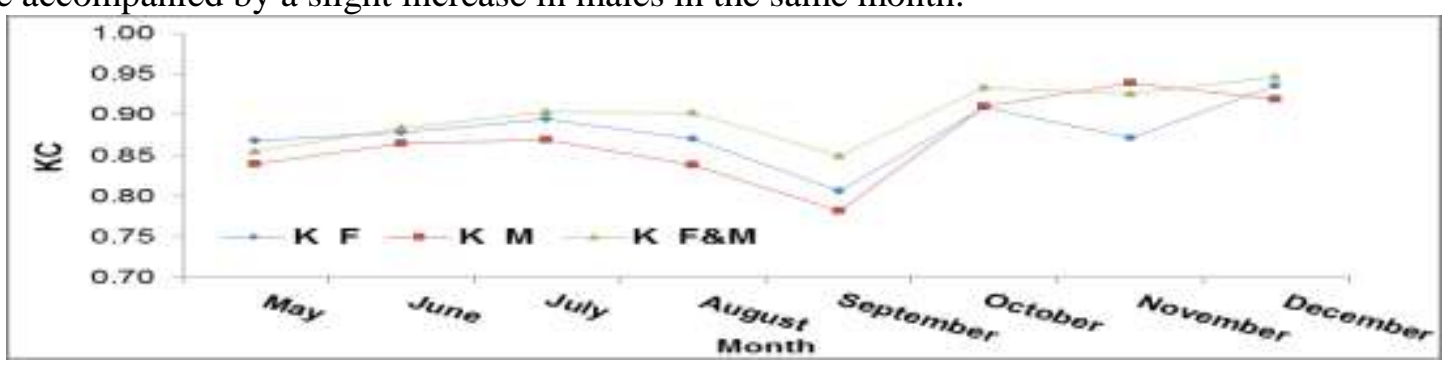

Fig 5: Monthly variation in condition factor $(\mathrm{K})$ of combined sexes $(\mathrm{F} \& M)$, females $(\mathrm{F})$ and males (M) of L. ramada during 2017.

\section{Sex ratio:}

It was seen from sex distribution in Table (1) that the two sexes did not distributed in the same proportion during different months. Females predominated during all months except in December, since it constitute more than $50 \%$ of the collected sample during the period of study.Overall ratio of males to females (M: F) was 1: 1.28. This means that the existed number of females was relatively higher than males.

Table 1: Monthly variations in sex ratio of Liza ramada from Bardawil lagoon during the fishing season 2017.

\begin{tabular}{|c|c|c|c|c|c|c|}
\hline & & \multicolumn{2}{|c|}{ Males } & \multicolumn{2}{c|}{ Females } & sex ratio \\
\hline Month & No. of fish & NO & $\%$ & NO & $\%$ & M/F \\
\hline May & 52 & 24 & 46.2 & 28 & 53.8 & $1-1.17$ \\
\hline June & 35 & 16 & 45.7 & 19 & 54.3 & $1-1.19$ \\
\hline July & 45 & 19 & 42.2 & 26 & 57.8 & $1-1.37$ \\
\hline August & 51 & 22 & 43.1 & 29 & 56.9 & $1-1.32$ \\
\hline September & 50 & 21 & 42.0 & 29 & 58.0 & $1-1.38$ \\
\hline October & 69 & 26 & 37.7 & 43 & 62.3 & $1-1.65$ \\
\hline November & 94 & 41 & 43.6 & 53 & 56.4 & $1-1.29$ \\
\hline December & 67 & 34 & 50.7 & 33 & 49.3 & $1-0.97$ \\
\hline & 463 & 203 & 43.8 & 260 & 56.2 & $1-1.28$ \\
\hline
\end{tabular}

\section{Gonado- Somatic Index (GSI):}

Gonad development was followed using the GSI. The reproduction period (expressed by GSI) of Liza ramada was determined to be in November and December, since GSI peaked in these two monthes (7.01 and $6.96 \%$ respectively). L. ramada has a long spawning season, extends from August to December. GSI of the males was lower than that of females. GSI of the females increased rapidly from August to December. The lowest values of Gonado Somatic Index (GSI) was recorded in May (0.38), (Fig.6).

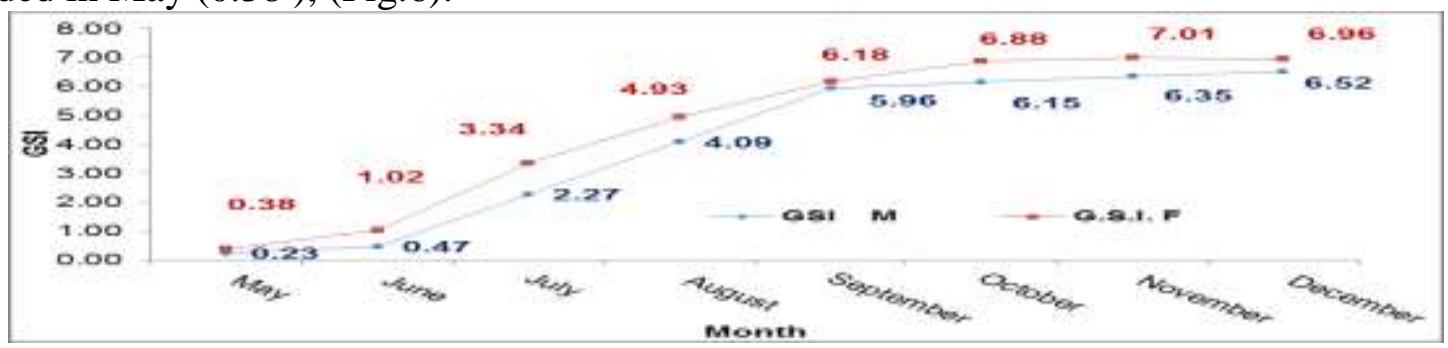

Fig. 6: Changes in Gonado Somatic Index (GSI) of Liza ramada in Bardawil lagoon during 2017. 
The immature and mature fish for each length group was analyzed to determine the length at first maturity $\left(\mathrm{L}_{\mathrm{m}}\right)$ (Table 2$)$. All males and females are mature at a total length higher than 25 and $26 \mathrm{~cm}$ respectively. The length at first maturity $\left(\mathrm{L}_{\mathrm{m}}\right)$ was determined as 27.6 and $28.9 \mathrm{~cm}$ for males and females respectively (Fig. 7).

Table 2: The percentage of mature and immature fishes of different length groups of Liza ramada from Bardawil lagoon during 2017.

\begin{tabular}{|c|c|c|c|c|c|c|c|c|c|c|}
\hline \multirow{2}{*}{$\begin{array}{c}\text { L } \\
\text { groups(cm) }\end{array}$} & \multirow{2}{*}{ Av. } & \multicolumn{2}{|c|}{ Immature } & \multicolumn{2}{|c|}{ Mature } & \multicolumn{2}{|c|}{ Immature } & \multicolumn{2}{c|}{ Mature } \\
\hline & & No & $\%$ & No. & $\%$ & & No. & $\%$ & No. & $\%$ \\
\hline $\mathbf{1 5 - 1 5 . 9}$ & 15.7 & 3 & 100.0 & & 0.0 & 15.5 & 2 & 100 & & 0.0 \\
\hline $\mathbf{1 6 - 1 6 . 9}$ & 16.5 & 8 & 100.0 & & 0.0 & 16.3 & 2 & 50.0 & 2 & 50.0 \\
\hline $\mathbf{1 7 - 1 7 . 9}$ & 17.5 & 5 & 100.0 & & 0.0 & 17.4 & 4 & 80.0 & 1 & 20.0 \\
\hline $\mathbf{1 8 - 1 8 . 9}$ & 18.6 & 3 & 100.0 & & 0.0 & 18.4 & 3 & 50 & 3 & 50.0 \\
\hline $\mathbf{1 9 - 1 9 . 9}$ & 19.5 & 5 & 71.4 & 2 & 28.6 & 19.5 & 3 & 33.3 & 6 & 66.7 \\
\hline $\mathbf{2 0 - 2 0 . 9}$ & 20.5 & 3 & 75.0 & 1 & 25.0 & 20.1 & 0 & 0.0 & 5 & 100 \\
\hline $\mathbf{2 1 - 2 1 . 9}$ & 21.6 & 4 & 33.3 & 8 & 66.7 & 21.4 & 6 & 42.9 & 8 & 57.1 \\
\hline $\mathbf{2 2 - 2 2 . 9}$ & 22.4 & 8 & 40.0 & 12 & 60.0 & 22.5 & 6 & 35.3 & 11 & 64.7 \\
\hline $\mathbf{2 3 - 2 3 . 9}$ & 23.5 & 7 & 46.7 & 8 & 53.3 & 23.4 & 5 & 38.5 & 8 & 61.5 \\
\hline $\mathbf{2 4 - 2 4 . 9}$ & 24.4 & 11 & 52.4 & 10 & 47.6 & 24.4 & 6 & 46.2 & 7 & 53.8 \\
\hline $\mathbf{2 5 - 2 5 . 9}$ & 25.5 & 8 & 61.5 & 5 & 38.5 & 25.3 & 4 & 36.4 & 7 & 63.6 \\
\hline $\mathbf{2 6 - 2 6 . 9}$ & 26.4 & 10 & 45.5 & 12 & 54.5 & 26.5 & & 0.0 & 20 & 100 \\
\hline $\mathbf{2 7 - 2 7 . 9}$ & 27.5 & & 0.0 & 15 & 100 & 27.6 & & 0.0 & 5 & 100 \\
\hline $\mathbf{2 8 - 2 8 . 9}$ & 28.6 & & 0.0 & 20 & 100 & 28.5 & & 0.0 & 13 & 100 \\
\hline $\mathbf{2 9 - 2 9 . 9}$ & 29.4 & & 0.0 & 42 & 100 & 29.5 & & 0.0 & 42 & 100 \\
\hline $\mathbf{3 0 - 3 0 . 9}$ & 30.3 & & 0.0 & 6 & 100 & 30.3 & & 0.0 & 3 & 100 \\
\hline $\mathbf{3 1 - 3 1 . 9}$ & 31.5 & & 0.0 & 14 & 100 & 31.5 & & 0.0 & 7 & 100 \\
\hline $\mathbf{3 2 - 3 2 . 9}$ & 32.3 & & 0.0 & 11 & 100 & 32.3 & & 0.0 & 3 & 100 \\
\hline $\mathbf{3 3 - 3 3 . 9}$ & 33.4 & & 0.0 & 8 & 100 & 33.5 & & 0.0 & 2 & 100 \\
\hline $\mathbf{3 4 - 3 4 . 9}$ & 34.6 & & 0.0 & 7 & 100 & 34.3 & & 0.0 & 6 & 100 \\
\hline $\mathbf{3 5 - 3 5 . 9}$ & 35.5 & & 0.0 & 2 & 100 & 35.7 & & 0.0 & 2 & 100 \\
\hline $\mathbf{3 6 - 3 6 . 9}$ & 36.4 & & 0.0 & 2 & 100 & 36.5 & & 0.0 & 1 & 100 \\
\hline & & 75 & & 185 & 71.2 & & 41 & & 162 & \\
\hline
\end{tabular}

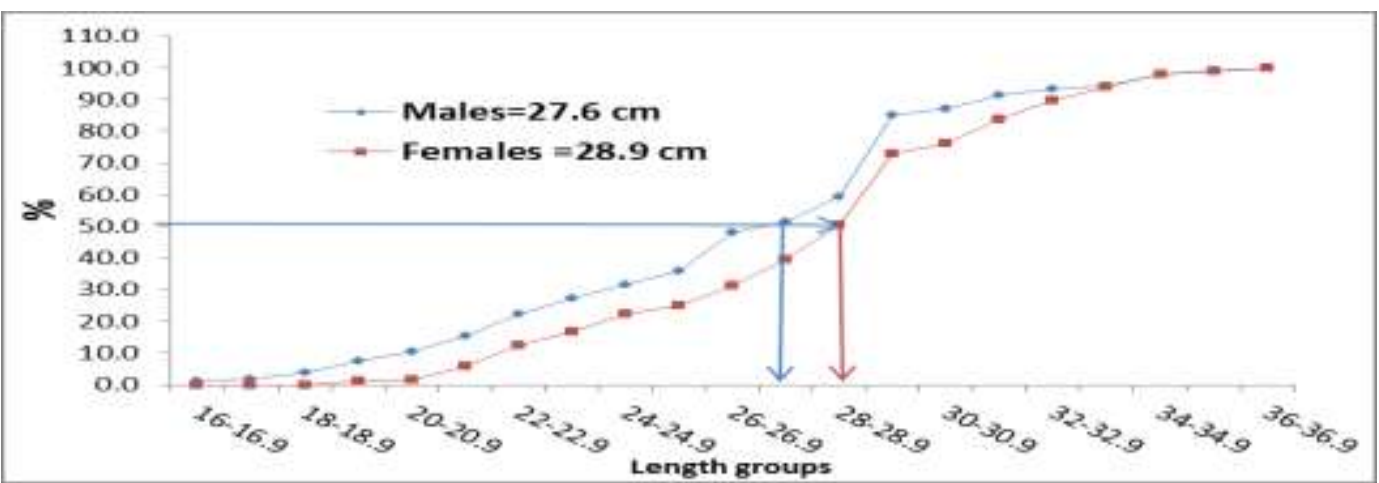

Fig. 7: Length at first maturity $\left(\mathrm{L}_{\mathrm{m}}\right)$ of males and females of Liza ramada in Bardawil lagoon during 2017.

The relation between body size (total length and body weight) and fecundity (absolute and relative) of L. ramada were illustrated in Table (3). The number of eggs gradually increased by increasing fish length or weight, since fish of $21.2 \mathrm{~cm}(88.6$ g.) lay about 247230 eggs, reaching maximum of about 1299540 eggs at fish length $36.7 \mathrm{~cm},(433.9 \mathrm{gm}$.). 
Table 3: Absolute fecundity of Liza ramada from Bardwil lagoon during 2017.

\begin{tabular}{|c|c|c|c|c|c|}
\hline L group(cm) & No. & Av. L & Av. Abs. Fec. & Min. & Max. \\
\hline $\mathbf{2 1 - 2 2}$ & 2 & 21.4 & 273240.0 & 247230 & 299250 \\
\hline $\mathbf{2 2 - 2 3}$ & 4 & 22.5 & 327865.0 & 303840 & 345100 \\
\hline $\mathbf{2 3 - 2 4}$ & 2 & 23.6 & 369970.0 & 339040 & 400900 \\
\hline $\mathbf{2 4 - 2 5}$ & 2 & 24.5 & 391800.0 & 369600 & 414000 \\
\hline $\mathbf{2 5 - 2 6}$ & 3 & 25.4 & 444580.0 & 426240 & 468300 \\
\hline $\mathbf{2 6 - 2 7}$ & 2 & 26.2 & 513000.0 & 511200 & 514800 \\
\hline $\mathbf{2 7 - 2 8}$ & 4 & 27.5 & 564625.0 & 486200 & 614100 \\
\hline $\mathbf{2 8 - 2 9}$ & 7 & 28.4 & 729675.7 & 707400 & 761600 \\
\hline $\mathbf{2 9 - 3 0}$ & 7 & 29.4 & 816521.4 & 746200 & 858480 \\
\hline $\mathbf{3 0 - 3 1}$ & 3 & 30.1 & 892290.0 & 852110 & 950040 \\
\hline $\mathbf{3 1 - 3 2}$ & 5 & 31.4 & 901656.0 & 866700 & 979200 \\
\hline $\mathbf{3 2 - 3 3}$ & 8 & 32.3 & 1051998.8 & 912600 & 1118000 \\
\hline $\mathbf{3 3 - 3 4}$ & 6 & 33.4 & 1027793.3 & 798080 & 1177300 \\
\hline $\mathbf{3 4 - 3 5}$ & 5 & 34.5 & 1128974.0 & 962560 & 1252080 \\
\hline $\mathbf{3 5 - 3 6}$ & 2 & 35.5 & 1239850.0 & 1228500 & 1251200 \\
\hline $\mathbf{3 6 - 3 7}$ & 2 & 36.4 & 1275720.0 & 1251900 & 1299540 \\
\hline & 64 & & & & \\
\hline
\end{tabular}

The absolute fecundity was increased with a total length and described by power equation $\mathrm{F}=\mathrm{a} \mathrm{L}^{\mathrm{b}}$ since $\mathrm{F}=27.958 \mathrm{~L}^{\mathbf{3 . 0 1 3 5}},\left(\mathrm{R}^{2}=0.9458\right)$. The relative fecundity gradually increased from 2851 to 5101 eggs per gm. The relative fecundity gradually increased from 11661.8 to 36098.3 eggs per $\mathrm{cm}$. The relation between fecundity and size was illustrated in Figs. 8 and 9.

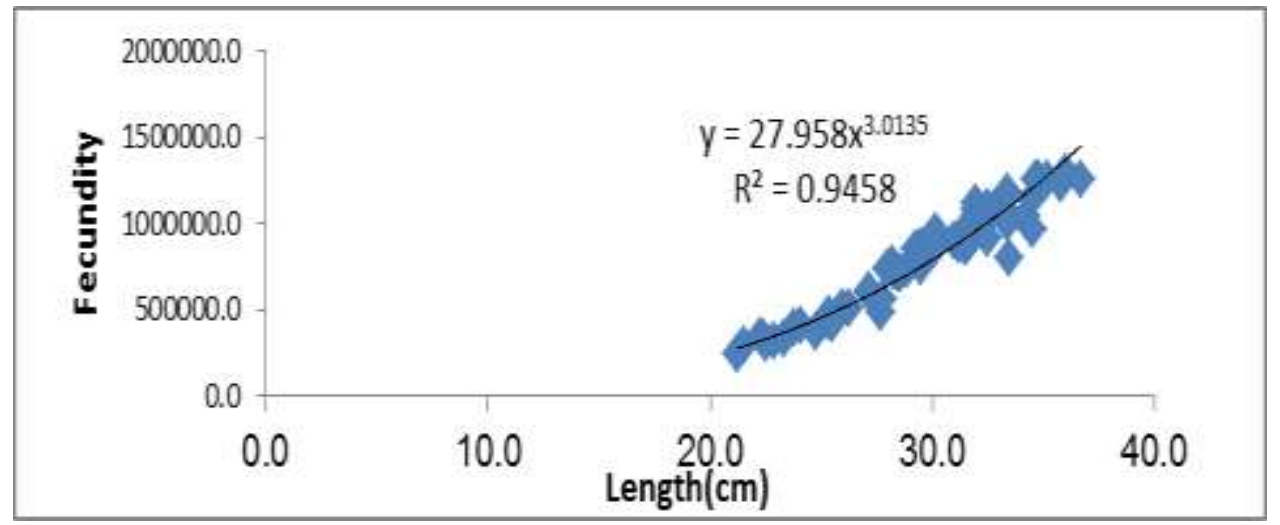

Fig. 8: Relationship between total length and Absolute fecundity of L. ramada collected from Bardawil lagoon, 2017.

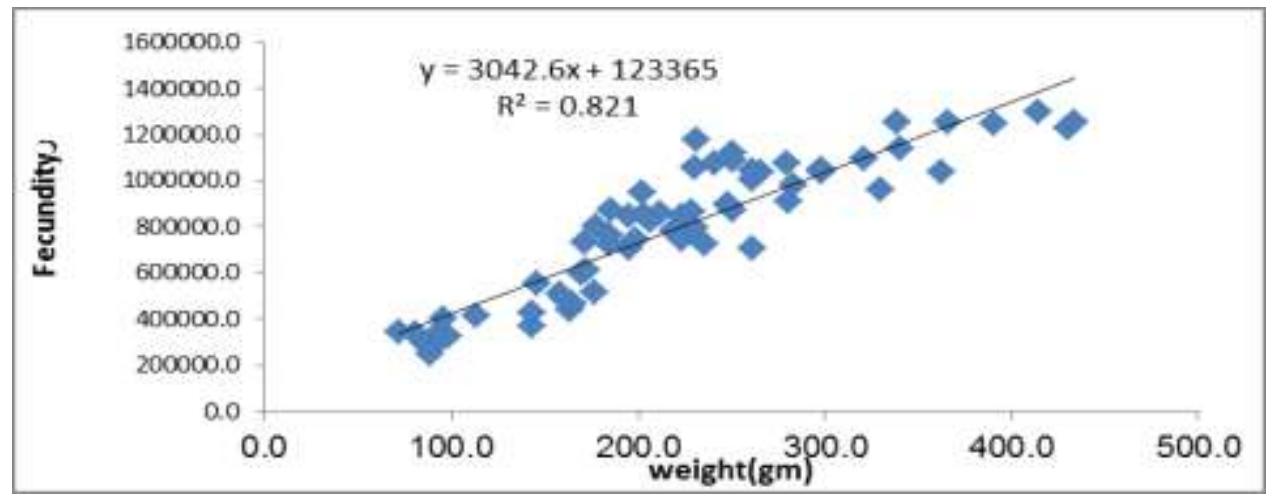

Fig. 9: Relationship between body weight (g) and Absolute fecundity of L. ramada collected from Bardawil lagoon, 2017. 


\section{DISCUSSION}

Mullets are important economic resources that support many small groups through both fishing and aquaculture (Pina \& Chaves 2005, Katselis et al. 2005). The Length-weight relationship is actual index of the condition of fish and alters over the year according to factors namely food availability, feeding rate, gonad development and spawning time (Bagenal and Tech, 1978). In the present study Length-weight relationship were $\mathrm{w}=0.0063 \mathrm{~L}^{3.0727}, \mathrm{~W}=0.0087 \mathrm{~L}^{2.98}$ and $\mathrm{W}=0.0095 \mathrm{~L}^{2.9505}$ of males, females and combined sexes respectively. Table 4 compare length -weight relationships regression parameters ( $\mathrm{a}$ and $\mathrm{b}$ ) of Liza ramada from different locations.

Table 4: Comparison of length $(\mathrm{cm})$-weight $(\mathrm{g})$ relationships regression parameters $(\mathrm{a}$ and $\mathrm{b})$ of Liza ramada from different locations .

\begin{tabular}{|l|l|l|l|}
\hline \multicolumn{1}{|c|}{ Author } & \multicolumn{1}{c|}{ Location } & \multicolumn{1}{c|}{ a } & \multicolumn{1}{c|}{ b } \\
\hline Mehanna( 2006) & Bardwil lagoon & 0.0052 & 3.13 \\
\hline Salem et al., (2010) & Bardwil lagoon & 0.0177 & 2.7642 \\
\hline Kasimoglu et al.,(2011) & The Southern Aegean Sea, Turkey & 0.0005 & 2.253 \\
\hline Mohamed (2016) & Bardwil lagoon & 0.017 & 2.764 \\
\hline $\begin{array}{l}\text { Present study (ô) } \\
\text { Present study (+) } \\
\text { Present study (combined sexes) }\end{array}$ & Bardwil lagoon & 0.0063 & 3.0727 \\
\cline { 2 - 4 } & Bardwil lagoon & 0.0087 & 2.98 \\
\cline { 2 - 4 } & Bardwil lagoon & 0.0095 & 2.9505 \\
\hline
\end{tabular}

Our results are lower than that recorded by (Mehanna, 2006). On the other hand, these results were higher than that obtained by (Salem et al., 2010 and Mohamed 2016) in Bardaweel Lagoon and (Kasimoglu et al., 2011) in the Southern Aegean Sea, Turkey, Table 4. Difference in ' $b$ ' values can be due to the combination of several factors such as number of specimens studied, habitat, and status of stomach fullness, gonadal maturity, sex, health and overall fish condition, and differences in the observed length ranges of the specimens caught (Abowei et al., 2009). In the present study, a decline was observed in the value of (K) during November in female and accompanied by slight increase in males. This may possibly due to some females begins to spawn in this month and consequently a decline in condition factors in female was occurred. Fish size and condition are key parameters to properly assess fecundity at the population level (Murua et al., 2003)

The availability of data based on reproductive parameters and environmental variation leads to a finer knowledge of observed variation in reproductive output and magnifies our ability to assess recruitment (Kraus et al., 2002). L. ramada have a long spawning season extends from Augusts to December. GSI of L. ramada was recorded in different months to confirm the spawning period. These results agree with that reported by (Salem et al., 2010 and Mohamed 2016) in Bardwell lagoon and with (El Halfway et al., 2007). Salem and Mohammed (1982) in Lake Timsah found that the GSI values of Liza ramada were 2.2, 4.3 and 2.2, in October, November and December respectively. Sagi and Abraham et al. (1985) reported that Liza ramada has topmost GSI values during the period of migration to the Sea. Yerli (1991) found that the values of GSI were 18.96 and 16.17 at November and December respectively.

In the present study, sex ratio of $L$ ramada was about one male to 1.3 female (1.0:1.28) with percentage $43.8 \%$ and $56.2 \%$ for male and female respectively. This results agreed with (Kasimoglu et al. 2011) in the Southern Aegean Sea, Turkey, the sex ratio was one male to 1.26 female. Ergene (2000) in Akgöl-Paradeniz Lagoons (Göksü Delta) found that the sex ratio of L. ramada was $53.74 \%$ to $43.28 \%$ for females and males respectively. El-Halfway et al. (2007) recorded that the sex ratio of the collected sample 238 fish of Liza ramada in Lake Timsah was 1:1.7 male to 
female. Abd Alhafid and El-Mor (2014) studied the monthly variations in sex ratio between females $(159$ fish $=63.6 \%)$ and males $(91$ fish $=36.4 \%)$. Sex ratio was $(1$ : 1.75) for males to females respectively during all months and showed that the numbers of the females was dominated over the males.

Length at first maturity $\left(\mathrm{L}_{\mathrm{m}}\right)$ has a great importance in the determination of optimum mesh size ( Mehanna, 2007). In the present study the length at first maturity $\left(\mathrm{L}_{\mathrm{m}}\right)$ was determined as $\mathrm{L}_{\mathrm{m}}=27.6$ and $28.9 \mathrm{~cm}$ for males and females respectively. Muss and Dahlström (1978) found that, the length at first sexual maturity of $L$. ramada as $\mathrm{L}_{\mathrm{m}}=25.9 \mathrm{~cm}$, ranged between $25-32 \mathrm{~cm}$. El-Halfway et al. (2007) found that the smallest ripe male was $14 \mathrm{~cm}$ while the smallest ripe female was $16 \mathrm{~cm}$, and $\mathrm{L}_{\mathrm{m}}$ was at total length 18.6 and $19.8 \mathrm{~cm}$ for male and female respectively. In the present study, all males larger than $22 \mathrm{~cm}$ and females larger than $24 \mathrm{~cm}$ are sexually mature. Kaya (2010) reported that, the reason for these differences is that the first spawning age and size is affected by environmental factors such as temperature, feed consumption (quantity and quality) and the water systems in which the fish live.

In the present study the absolute fecundity was increased with total length and described by power equation $\mathrm{F}=\mathrm{a} \mathrm{L}$ as $\mathrm{F}=27.958 \mathrm{~L}^{3.0135} \quad\left(\mathrm{R}^{2}=0.9458\right)$ and the relative fecundity gradually increased from 11661.8 to 36098.3 eggs per $\mathrm{cm}$. The absolute fecundity reported by other workers for L. ramada, (Farrugio and Quignard ,1973) in Tunis reported an absolute fecundity of 82202 to 434787 eggs and relative fecundity of 604 to 1454 eggs per $1 \mathrm{~g}$ for lengths ranging from 255 to $345 \mathrm{~mm}$ (SL). In Egypt, (El Maghraby et al., 1974) reported 45568 to 316828 eggs absolute fecundity and 728 to 992 eggs per 1 g relative fecundity. Abdalhafid and El-Mor (2014) estimated the fecundity of L. ramada from Ain El-Ghazala lagoon (Libya) as 51231 to 236557 eggs in fishes ranged in length from 16.5 to $32.4 \mathrm{~cm}$. Albieri and Araújo (2010) mentioned that, high fecundity would be a tactic to enable success in M. liza recruitment to the Sepetiba bay in tropical Brazilian. Hickling (1970), in southern England, found only two ripening females of L. ramada with 581000 and 1 243000 eggs with lengths 490 to $530 \mathrm{~mm}$, respectively. Ergene (2000) found 234 720 to 435265 eggs for ages III and IV respectively. These differences can be attributed either to the high spatial variation of the studies, thus to different environmental conditions or to the methods used that produce variable results (e.g., counting or not the oocytes that will not mature), but mainly to the differences in length, weight or age in the samples of the different authors, since absolute fecundity increases as those parameters increase (Hotos et al. 2000).

\section{CONCLUSION}

It could be concluded that, Liza ramada in Bardawil Lagoon has a long spawning season extends from August to December, with a peak during November and December. Overall ratio of males to females (M: F) was 1: 1.28. The length at first mature $\left(\mathrm{L}_{\mathrm{m}}\right)$ was determined as 27.6 and $28.9 \mathrm{~cm}$ for males and females respectively. It is recommonded to ban the use of gears of illegal mesh sizes and other destructive fishing methods, and increase mesh size used in Bardaweel Lagoon to catch $L$. ramada to lengths greater than $29.0 \mathrm{~cm}$, to protect $L$. ramada from exploitation and permit the females to breed, grow, and recruit into the fisheries ground. 


\section{REFERENCES}

Abdalhafid, Y. K and El-Mor, M. (2014). Some aspects of the reproductive biology of the thin lip grey mullet Liza ramada (Risso, 1826) in Ain El-Ghazala lagoon-eastern Libya. International journal of bioassays, 3 (04): 2041-2044.

Abowei, J. F. N.; Daviesand, O. A. and Eli, A. A. (2009). Study of the length -weight relationship and condition factor of five fish species from Nkoro River,Niger Delta, Nigeria. Curr. Res. J. Bio. Sci. 1(3): 94-98.

Albieri,R.J. and Araújo, F. G. (2010). Reproductive biology of the mullet Mugil liza (Teleostei: Mugilidae) in a tropical Brazilian bay ZOOLOGIA 27 (3): 331-340.

Bagenal, T. B. and Tesch, F. W. (1978). Age and growth In: T.Bagena, editor, methods for assessment of fish production in fresh waters . IBp handbook No.3 (3rded) Black well sci. publications, oxford. pp 101-136(chapter 5).

EL-Ganainy, A. A.; E. T Mostafa and Omran, M. A. (2002). Fisheries status of the stribed Mullet (pisces: Mugilidae) from Bardawil Lagoon. Egypt. J. Aquat. Biol. \& Fish. 6: 47-65.

EL-Halfawy, M.; Ramadan, A. M. and Mahmoud W. F. (2007). Reproductive biology and histological studies of the grey mullet, Liza ramada, (RISSO, 1826) in Lake Timsah, Suez Canal. Egyptian J. Aquatic Res., 33 (1): 434-454.

El Maghraby, A.M.; Hashem, M.J. and El Sedfy, H.M. (1974). Sexual maturity, spawning migration and fecundity of $\mathrm{M}$. capito in Lake Borullus. Bulletin of the Institute of Oceanography and Fisheries, ARE, 4: 35-56.

Ergene, S. (2000). Reproduction Characteristics of Thinlip Grey Mullet, Liza ramada (Risso, 1826) Inhabiting Akgöl-Paradeniz Lagoons (Göksü Delta), Turk J Zool, 24: 159-164.

Farrugio, H. and Quignard , J.P. (1973). Biologie de Mugil (Liza) ramada Risso, 1826 et de Mugil (Chelon) labrosus Risso, 1826 (Poissons, Teleosteens, Mugilides) du lac de Tunis. Taille de premiere maturite sexuelle, cycle et fecondite. Bulletin de l'Institut National Scientifique et Technique d'Oceanographie et de Peche de Salammbo 2 (4): 565-578.

GAFRD (2016). Report of General Authority for Fish Resources Development on Egyptian Fishery.

Hickling, C.F. (1970). A contribution to the natural history of the English grey mullet [Pisces, Mugilidae]. Journal of the Marine Biological Association of the United Kingdom 50 (3): 609-633. DOI: 10.1017/S0025315400004914.

Hile, R. (1936). Age and growth of the Cisco Leucichthys arted in the lakes of the north eastern high lands, Wisconsin. Bull. U. S. Bur. Fish., 48: 211-317.

Hotos, G.N., Avramidou D., Ondrias I. (2000). Reproduction biology of Liza aurata (Risso, 1810), (Pisces: Mugilidae) in the lagoon of Klisova (Messolonghi, W. Greece). Fisheries Research, 47 (1): 57-67.

Hunter, J.R.; Macewicz, B.J.; Lo, N.C.H. and Kimbrell, C.A. (1992). Fecundity, spawning and maturity of female Dover Sole, Microstomus pacificus, with an evaluation of assumptions and precision. Fisheries Bulletin of United States, 90: 101-128.

Kasimoğlu, C.; Yilmaz, F. and Koc, H. T. (2011). Growth and Reproductive characteristics of the Thin-lipped Grey Mullet, Liza ramada (Risso, 1826) Inhabiting in Gökova Bay (Muğla), the Southern Aegean Sea, Turkey. BAÜ Fen Bil. Enst. Dergisi Cilt, 13(2): 35-49.

Katselis G.; Koutsikopoulos, C.; Rogdakis, Y.; Lachanas, T.; Dimitriou, E. and Vidalis, K. (2005). A model to estimate the annual production of roes 
(avgotaracho) of flathead mullet (Mugil cephalus) based on the spawning migration of species. Fishery Research, 75: 138-148

Kaya, N. (2010). A Study on Some Biological Properties of Liza abu (Heckel, 1846) Living in Devegeçidi Dam Lake (Diyarbakır). Masters thesis, Yüzüncü Y1l Üniversitesi, Fen Bilimleri Ens., Van, pp. 62. (In Turkish).

Keith, P.; Le Bail, P.Y. and Planquette, P. (2000).Atlas des poissons d'eau douce de Guyane (tome 2, fascicule I). Publications Scientifiques du Muséum National d'Histoire Naturelle, 286 p, Paris.

Khalil, M. T.; Saad, A. A.; Ahmed, M.H.M.; El Kafrawy, S. B. and Emam, W.W.M. (2016). Integrated Field Study, Remote Sensing and GIS Approach for Assessing and Monitoring Some Chemical Water Quality Parameters in Bardawil Lagoon, Egypt. Int. Inno.Res.Scie., Eng. \& Techno. 5(8): 1465614669.

Kraus, G.; Tomkiewicz, J. and Kõster, F.W. (2002). Egg production of Baltic cod in relation to variable sex ratio, maturity and fecundity. Candian J. Fish. Aquat. Sci., 59: 1908-1920.

Mehanna,. S. F. (2006).Fisheries management of the thinlip Grey mullet Liza ramada and golden grey mullet Liza aurata from lake Bardawil Egypt. J. Aquat. Biol. \& Fish., 10(2): 33 -53.

Mehanna, S.F. (2007). Stock assessment and management of the Egyptian Sole Solea aegyptiaca Chabanaud, 1927 (Osteichthyes: Soleidae), in the Southeastern Mediterranean, Egypt. Turkish J. Zool., 31: 379-388.

Mehanna, S.F. (2014). Reproductive dynamics of the common sole Solea solea (Linnaeus, 1758) from Bardawil lagoon, North Sinai, Egypt. Tropentag 2014: Conference on International Research on Food Security, Natural Resource Management and Rural Development. Organized by the Czech University of Life Sciences Prague.

Mehanna, S.; A. El-Aiatt and Salem, M. (2011). An investigation of the impacts of shrimp bottom trawling on the Bardawil lagoon fisheries, Egypt. $4^{\text {th }}$ International conference on Fisheries and Aquaculture, 3-5 October, Cairo, Egypt. (Egyptian J. of Aquatic Biology and Fisheries., 15:(3): 407-416.

Mohamed,A.A.M.(2016).Biological and fisheries studies of the thin lip grey mullet liza ramada fish in Bardawil lagoon, Msc. Thes. Fac. Enviro. Agric. Scie. Suez Canal Univ.

Murua, H., G. Kraus, F. Saborido-Rey, P.R. Witthames, A. Thorsen and S. Junquera. (2003). Procedures to estimate fecundity of marine fish species in relation to their reproductive strategy J. Northwest Atlantic Fish. Sci., 33: 33-54.

Muus, B. and Dahlström, P. (1978). Meeresfische der Ostsee, der Nordsee, des Atlantiks. BLV Verlagsgesellschaft, München. 244 pp.

Papa, R., Marzano, F.N., Rossi, V., Gandolfi, G. (2003). Genetic diversity and adaptability of two species of Mugilidae (Teleostei: Perciformes) of the Po river delta coastal lagoons, Oceanologica Acta, 26: 121-128.

Parameswarn, S.; Sevaraj, C. and Radhakrishnan, S. (1974). Observation on the bilogy of Labeo gonius (Hamilton). Indian J. Fish., 21: 54-75.

Pina, J.V. and Chaves, P.T. (2005). A pesca de tainha e parati na Baía de Guaratuba, Paraná, Brasil. Acta Biológica Paranaense, 34: 103-113.

Sagi, G. and Abraham, M. (1985). Photoperiod and ovarian activity in the grey mullet L. ramada (Pisces. Mugilidae). Isra. J. Zool., 33. 1-9. 
Salem, M.; EL Aiatt, A. A. and Ameran, M. (2010). Age, growth, mortality and yield per recruit of Liza ramada in Bardawill lagoon, North Sinai, Egypt. Abbassa Intern. J. Aqua. The third sci. Conf., Al Azhar Univ., Cairo, 17 -18 October) .

Salem, S. A. and Mohammed, S. Z. (1982).Studies on Mugil seheli and Mugil capito in Lake Timsa. I. Age and growth .Bull. Inst Oceanog. Fish. ARE, 8(1): 29-48.

Yeldan, H. and D. Avşar (2000). A preliminary study on the reproduction of rabbit fish, Siganus rivulatus (Forsskål, 1775), in the northeastern Mediterranean. Turk. J. Zool., 24: 173-182.

Yerli, S.V. (1991). Köyceğiz Lagǘn Sistemindeki L. ramada (Risso. 1826) stoklari úzerine Yncelemeter. Doğa Tr. J. of Veterinary and Animal Sciences, 16: 103120.

\section{ARABIC SUMMARY}

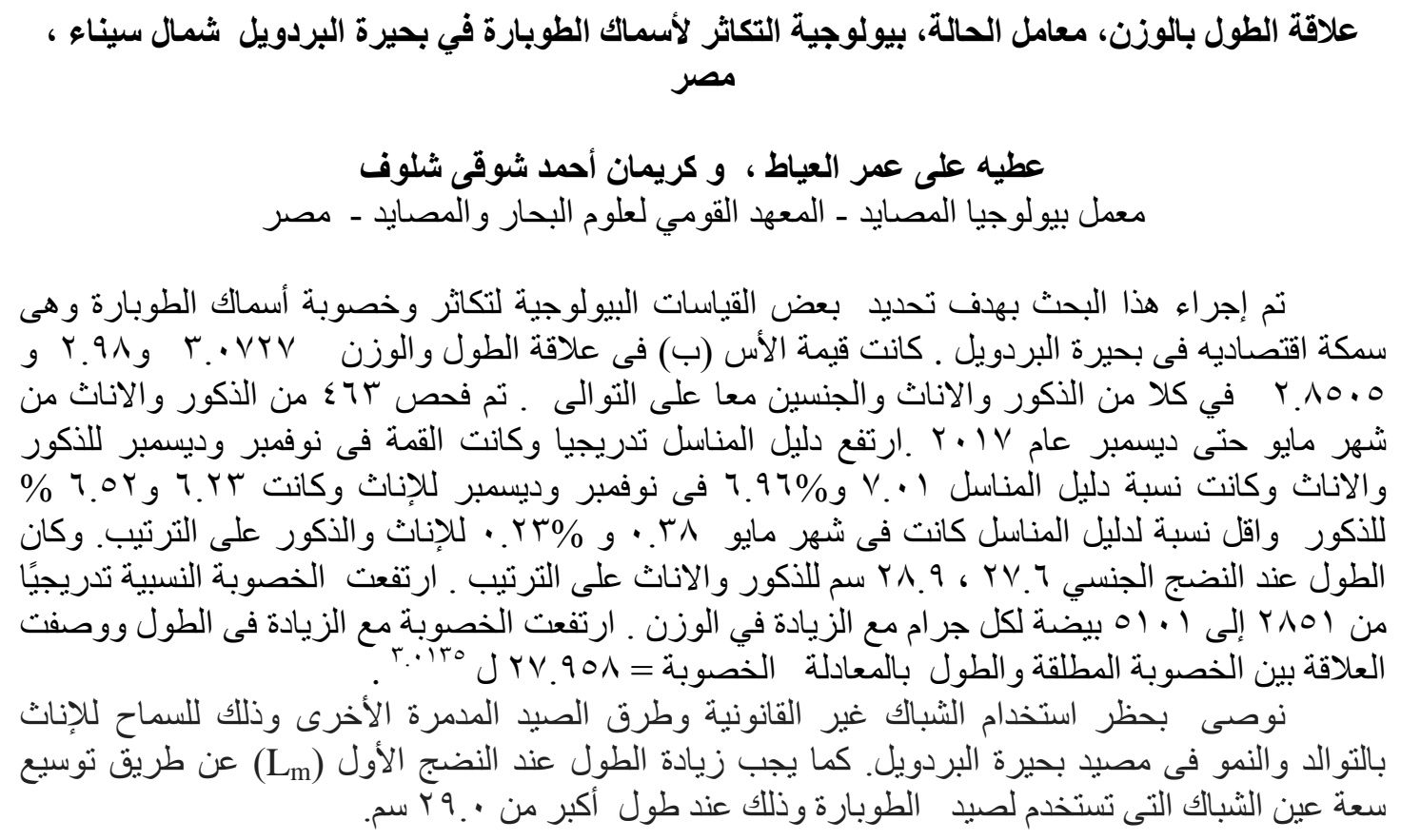

